\title{
BIOCHEMICAL ANALYSIS OF DIFFERENT NUTRITIONAL COMPONENTS OF CLARIAS BATRACHUS (LINNAEUS) AND C. GARIEPINUS (BURCHELL) IN RELATION TO PARASITIC INFESTATION
}

\author{
Sabina Yesmin and Hamida Khanum* \\ Department of Zoology,University of Dhaka,Dhaka-1000,Bangladesh
}

\begin{abstract}
Two catfish: Clarias batrachus (Linnaeus) and C. gariepinus (Burchell) were selected for examination during June, 2014 to May, 2016. The percentage (g/100 g) of nutrients such as moisture, ash, fat, protein, carbohydrate contents (mg/100 g) and energy (K cal) in C. batrachus and C. gariepinus was determined. Analyses were done to measure the nutrition value of edible body parts (flesh) of C. batrachus and C. gariepinus. The effects of modifying factors such as, season, sex, length, and diet of the hosts on the abundance of parasites were also studied. Present observation on biochemical analysis showed small variation in nutrient contents between C. batrachus and C. gariepinus. Protein, fat, moisture, carbohydrate levels were higher in non-infected C. batrachus (moisture $78.25 \pm$ $0.06 \mathrm{~g} / 100 \mathrm{~g}$, ash $1.42 \pm 0.09 \mathrm{~g} / 100 \mathrm{~g}$, fat $1.20 \pm 0.04 \mathrm{~g} / 100 \mathrm{~g}$, protein15.05 \pm $0.19 \mathrm{~g} / 100 \mathrm{~g}$, carbohydrate 5.53\%) and non-infected C. gariepinus (moisture $78.62 \pm 0.01 \mathrm{~g} / 100 \mathrm{~g}$, ash $1.22 \pm 0.10 \mathrm{~g} / 100 \mathrm{~g}$, fat $1.19 \pm 0.03 \mathrm{~g} / 100 \mathrm{~g}$, protein $14.69 \pm 0.07 \mathrm{~g} / 100 \mathrm{~g}$, carbohydrate $4.95 \%$ than those of infected $C$. batrachus and C. gariepinus. In both species the highest presence of most of the nutrient components was observed in winter.
\end{abstract}

Key words: Clarias batrachus, C. gariepinus, parasite, moisture, fat, ash, protein, carbohydrate

\section{INTRODUCTION}

The parasites may affect its host in various ways such as utilization of host's food, destruction of host tissue, abnormal growth, mechanical inferences, biological effects, various kinds of tissue reactions as well as the effects of toxins, poisons or secretion of parasites itself. Parasite has a wide range of distribution in all groups of animals. They are often described as occupying the aquatic, terrestrial - parasitic environments, and the body of another organism (Chandra 2004). Many studies have been carried out on the nutritional components of freshwater and marine fishes of Bangladesh, some of these are: Khuda and Khan (1962), Adhikari and Noor (1967), Ahmed et al. (1977), Ahmed and Hassan (1981 and 1982), Sultana (1989), Latifa et al. (1982 and 1985), Rubbi et al. (1985), Jafri (1969), Jacquot and Creach (1961). The nutritive values of fish can be greatly influenced by their chemical nature of their fats and other

* Author for correspondence: <hamida_khanum@yahoo.com >

(c) 2018 Zoological Society of Bangladesh DOI: https://doi.org/10.3329/bjz.v47i1.42018 
lipid components particularly cholesterol. Proximate composition has been reported to be a good pointer of physiology needed for routine analysis of fisheries (Cui and Wootton 2011).

Biochemical composition of fish shows very wide variation from one species to another, within the same species in different portions of the body, from season to season, according to age, size, growth etc. The important constituents of the fish in their order of magnitude are moisture, protein, fat, and minerals. Flesh from healthy fish contains $60-84 \%$ water, $15-24 \%$ protein and $0.1-2 \%$ fat. Lean fish have less than $0.5 \%$ fat and fatty fish have more than $2 \%$ fat (Haque 1975). Fish also serve as a favourite food stuff for large number of people across the globe due to its several health benefits. The catfish of the genus Clarias has a wide range of geographical distribution in the tropical region. In Bangladesh family Claridae has one indigenous species the Clarias batrachus (L.) and African magur Clarias gariepinus (Burchell 1822). In December 1989, African magur has been brought in Bangladesh from Thailand (Ali 1990). This species has already been successfully bred in Bangladesh. The African magur $C$. gariepinus has more weight and grow fast than C. batrachus. African catfish $C$. gariepinus is an exotic species. Fish farming offers an alternative solution to the increasing demand for fish and its protein (Ahmed et al. 2011).

In view of economic importance, to promote catfish culture for optimum production one of the main significant factors to control the parasite infestation for getting the better edible flesh of fish. Considering all the above mentioned studies made on C. batrachus and C. gariepinus it is aimed to study the different aspects of parasitic infestation and their role on growth and nutritional status. For this reason, it was needed to investigate the related aspects of $C$. batrachus and C. gariepinus, to determine the deterioration of nutritional components due to parasitic infection in the two species of Clarias.

\section{MATERIAL AND METHODS}

One hundred Clarias batrachus and fifty C. gariepinus were examined during June, 2014 to May, 2016. The hosts were collected from the cultural water body situated in Matikata, Dhaka Cantonment. After collection, the fishes were kept in the laboratory of the Department of Zoology, University of Dhaka and examined immediately. Fish were numbered serially, and then length, weights were measured and sexes were determined.

For biochemical analysis, the freshly collected sample (edible fish flesh) was initially washed with tap water and then dried with blotting paper. These were immediately kept in a dessicator to avoid further evaporation of the moisture. The samples were used for the determination of proximate composition such as 
moisture, fat, protein and carbohydrate of host fish muscle following Gopalan et al. (1971). Correlation-coefficient was calculated by Linear regression and multiple regression methods.

\section{RESULTS AND DISCUSSION}

Each of the study years was divided into three seasons: summer, rainy and winter. The abundance of parasites group in Clarias batrachus and C. gariepinus differs from each other in different months and seasons. The highest prevalence of infestation in C. batrachus and intensity of parasite in C. gariepinus was in winter, while in reverse, the highest prevalence of infestation in C. gariepinus and intensity of parasites in C. batrachus was in rainy season. The results of the proximate composition of $C$. batrachus and C. gariepinus have been analyzed to compare the values of components in the two species of infected and noninfected fishes, in different size groups and also to determine the relationship of the nutritional components with the rate of infestation.

In infected C. batrachus, the moisture was $77.07 \pm 0.01 \mathrm{~g} / 100 \mathrm{~g}$, ash $1.03 \pm$ $0.3 \mathrm{~g} / 100 \mathrm{~g}$, fat $1.07 \pm 0.07 \mathrm{~g} / 100 \mathrm{~g}$, protein $14.57 \pm 0.15 \mathrm{~g} / 100 \mathrm{~g}$ and carbohydrate $4.08 \%$. While, in non-infected C. batrachus the different nutritional elements were: moisture $78.25 \pm 0.06 \mathrm{~g} / 100 \mathrm{~g}$, ash $1.42 \pm 0.09 \mathrm{~g} / 100 \mathrm{~g}$, fat 1.20 $\pm 0.04 \mathrm{~g} / 100 \mathrm{~g}$, protein $15.05 \pm 0.19 \mathrm{~g} / 100 \mathrm{~g}$, carbohydrate $5.53 \%$ and ash 1.08 $\pm 0.03, \mathrm{~g} / 100 \mathrm{~g}$ fat $1.06 \pm 0.07 \mathrm{~g} / 100 \mathrm{~g}$, protein $14.15 \pm 0.04 \mathrm{~g} / 100$ carbohydrate $4.16 \%$. Besides these, in infected C. gariepinus, moisture was $77.53+0.01 \mathrm{~g} / 100 \mathrm{~g}$, ash $1.08+0.03 \mathrm{~g} / 100 \mathrm{~g}$ fat $1.06+0.07 / 100 \mathrm{~g}$, protein $14.15+0.04 \mathrm{~g} / 100$, carbohydrate $4.16 \%$ while, the non-infected C. gariepinus contains the nutritional components as the moisture $78.62 \pm 0.01 \mathrm{~g} / 100 \mathrm{~g}$, ash $1.22 \pm 0.10 \mathrm{~g} / 100 \mathrm{~g}$ fat $1.19 \pm 0.03 \mathrm{~g} / 100 \mathrm{~g}$, protein $14.69 \pm 0.07 \mathrm{~g} / 100 \mathrm{~g}$, carbohydrate $4.95 \%$ and energy $85.17 \%$ (Figs 1, 2).

The infected C. batrachus and C. gariepinus provided low nutrients value than those of non-infected fishes. The infected $C$. batrachus provided higher presence of protein content (14.57 $\pm 0.38 \mathrm{~g} / 100 \mathrm{~g})$ than infected C. gariepinus $(13.98 \pm 0.07 \mathrm{~g} / 100 \mathrm{~g})$ and rest of the components such as: moisture, ash, fat, carbohydrate and energy were higher in infected C. gariepinus than those of infected $C$. batrachus. In non-infected $C$. batrachus, the fat, ash, protein, carbohydrate found lower than the non-infected C. gariepinus except the moisture (Figs 1, 2). 

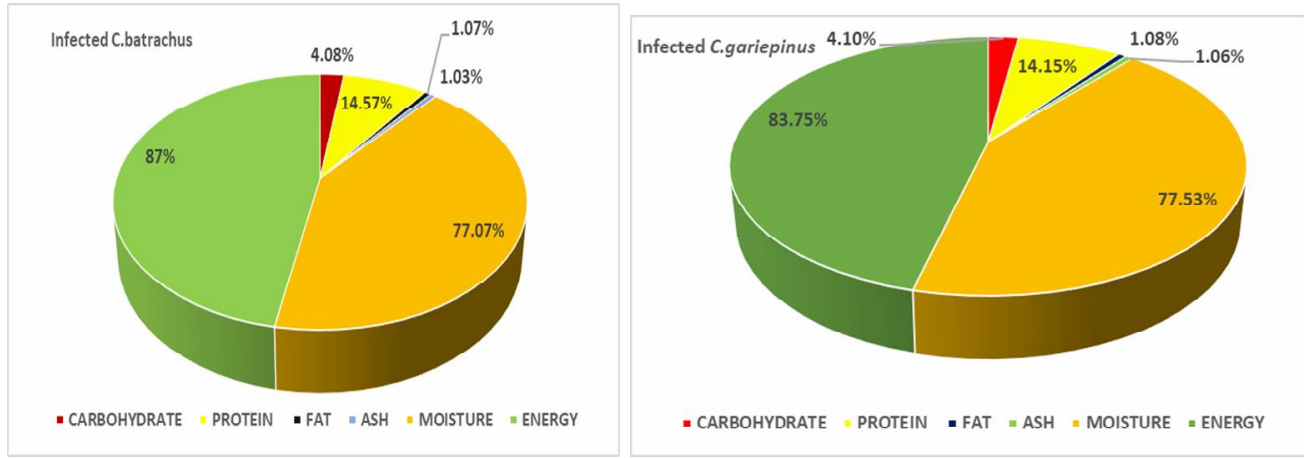

Fig. 1. The percentage of the nutritional values among infected and non-infected C. batrachus.

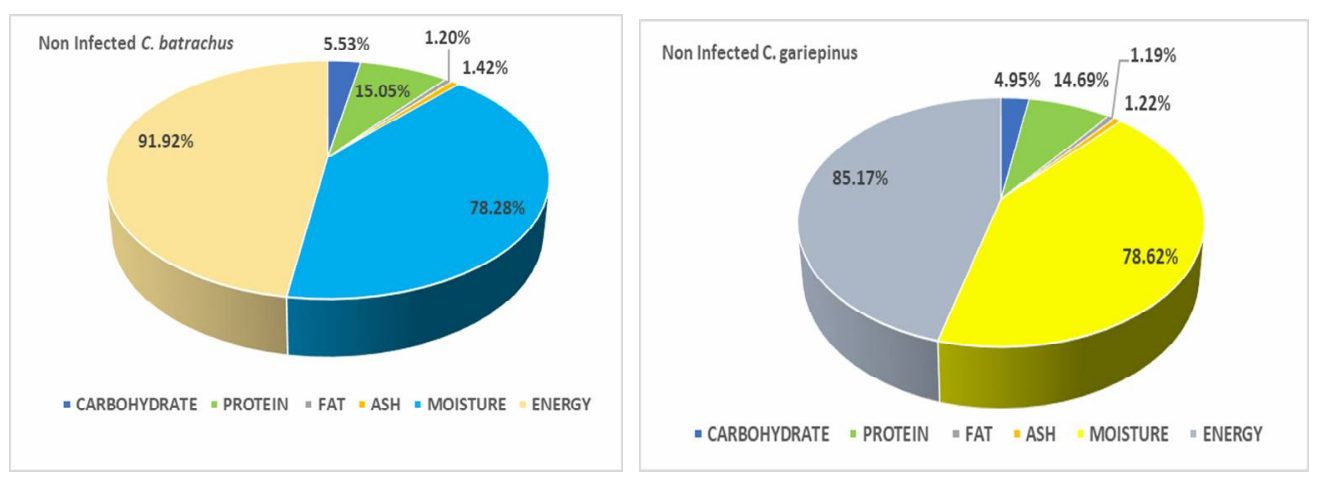

Fig. 2.The percentage of nutritional components among infected and non-infected C. gariepinus.

\section{Variation in different nutritional components in $C$. batrachus and $C$. gariepinus}

Protein: The protein content was slightly higher in C. batrachus (15.05 \pm $0.32)$ than C. gariepinus (14.69 \pm 0.16$)$. The value of protein was higher in noninfected $C$. batrachus $(15.05 \pm 0.32)$ than infected $C$. batrachus $(14.57 \pm 0.65)$. Similarly, the percentage of protein components was observed higher in noninfected C. gariepinus (14.69 \pm 0.16$)$ than in infected C. gariepinus $(14.15 \pm 0.43)$ fish (Figs 1,2). The highest percentage of protein value in C. batrachus was during winter (16.06 $\pm 0.50 \mathrm{~g} / 100 \mathrm{~g}$, in December, 2014 and $16.02 \pm 0.07 \mathrm{~g} / 100$ $\mathrm{g}$, in December, 2015). The lowest protein values were observed during rainy season (14.2 \pm 0.15 , in July, 2014 and 14.01 \pm 0.71 , in July, 2015). In C. gariepinus, the protein contents represented yearly peak of accumulation during winter (January, 2015, $14.89 \pm 0.17 \mathrm{~g} / 100 \mathrm{~g}$ and February, 2016, $15.01 \pm 0.04$ $\mathrm{g} / 100 \mathrm{~g})$. The lowest percentage of protein was observed during rainy season (September, 2014, $13.27 \pm 0.38 \mathrm{~g} / 100 \mathrm{~g}$ and September, 2015, $13.65 \pm 0.13$ 
g/100 g). Higher prevalence and intensity of infestation was in C. batrachus and C. gariepinus observed during winter and summer (Fig. 3).

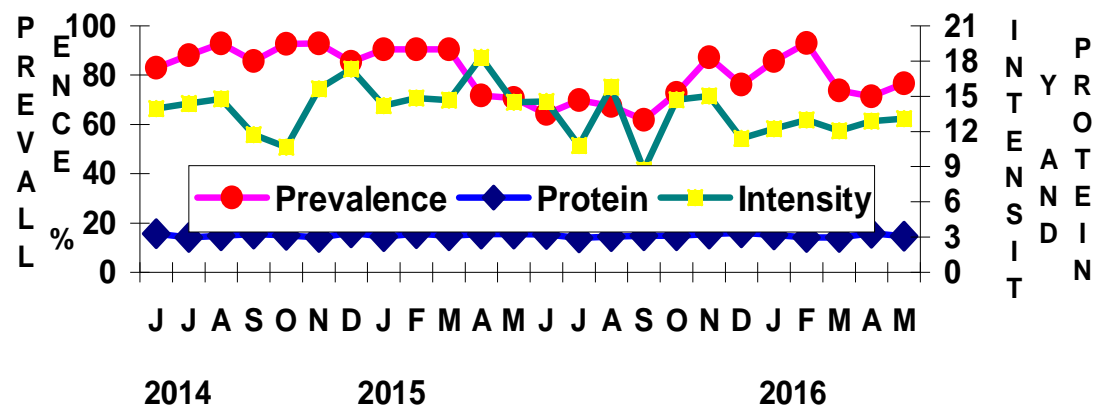

Fig. 3. Correlation of protein content with intensity and infestation of total parasite in C. batrachus.

Table 1. Percentage of nutritional component in different length groups of $\mathrm{C}$. batrachus

\begin{tabular}{ccccc}
\hline $\begin{array}{c}\text { Length } \\
\text { Groups }(\mathrm{cm})\end{array}$ & $\begin{array}{c}\text { Moisture } \\
(\mathrm{g} / 100 \mathrm{~g})\end{array}$ & $\begin{array}{c}\text { Protein } \\
(\mathrm{g} / 100 \mathrm{~g})\end{array}$ & $\begin{array}{c}\text { Fat } \\
(\mathrm{g} / 100 \mathrm{~g})\end{array}$ & $\begin{array}{c}\text { Carbohydrate } \\
(\%)\end{array}$ \\
\hline $12-16$ & $79.19 \pm 0.14$ & $14.11 \pm 0.50$ & $1.0 \pm 0.05$ & 3.9 \\
$17-21$ & $78.42 \pm 0.02$ & $14.4 \pm 0.07$ & $1.10 \pm 0.12$ & 4.04 \\
$22-26$ & $78.16 \pm 0.06$ & $14.9 \pm 0.15$ & $1.13 \pm 0.14$ & 4.6 \\
$27-31$ & $77.46 \pm 0.03$ & $15.1 \pm 0.71$ & $1.15 \pm 0.43$ & 4.9 \\
$32-36$ & $76.12 \pm 0.11$ & $15.56 \pm 0.65$ & $1.2 \pm 0.07$ & 5.03 \\
$37-41$ & $76.75 \pm 0.09$ & $16.06 \pm 0.45$ & $1.29 \pm 0.54$ & 5.58 \\
\hline
\end{tabular}

The average values of protein contents were high in larger size groups of Clarias spp. than the smaller groups. In C. batrachus, minimum percentage of protein $(14.11 \pm 0.50 \mathrm{~g} / 100 \mathrm{~g})$ was observed in largest length groups $(12-16 \mathrm{~cm})$ with gradual increase in the successive length group, the highest value (16.06 \pm $0.45 \mathrm{~g} / 100 \mathrm{~g})$ was found in the largest length group $(37-41 \mathrm{~cm})$ (Table 1). Similarly, in C. gariepinus, lowest percentage of protein $(13.65 \pm 0.17 \mathrm{~g} / 100 \mathrm{~g})$ was observed in the smallest $(16-21 \mathrm{~cm})$ size and highest value $(15.09 \pm 0.28$ $\mathrm{g} / 100 \mathrm{~g})$ was in the largest $(46-51 \mathrm{~cm}$ ) length group (Table 2). The changes of prevalence and mean intensity of total parasites in the Clarias spp. in different months and seasons was related with the variation of protein content. In $C$. batrachus, the correlation between the percentages of protein content with the prevalence of infestation was $r=-0.106, p>0.01$ and with intensity of parasite was $\mathrm{r}=0.203, \mathrm{p}>0.01$. In C. gariepinus, the protein content also showed more or less similar correlation with prevalence $(\mathrm{r}=0.231 ; \mathrm{p}>0.01$ and mean intensity $(\mathrm{r}=0.247, \mathrm{p}>0.01)$ (Table 3$)$. 
Table 2. Percentage of nutritional component in different length groups of $C$. gariepinus

\begin{tabular}{lcccc}
\hline $\begin{array}{l}\text { Length } \\
\text { groups }(\mathrm{cm})\end{array}$ & $\begin{array}{c}\text { Moisture } \\
(\mathrm{g} / 100 \mathrm{~g})\end{array}$ & $\begin{array}{c}\text { Protein } \\
(\mathrm{g} / 100 \mathrm{~g})\end{array}$ & $\begin{array}{c}\text { Fat } \\
(\mathrm{g} / 100 \mathrm{~g})\end{array}$ & $\begin{array}{c}\text { Carbohydrate } \\
(\%)\end{array}$ \\
\hline $16-21$ & $79.4 \pm 0.06$ & $13.65 \pm 0.17$ & $1.01 \pm 0.02$ & 3.95 \\
$22-27$ & $79.18 \pm 0.12$ & $13.87 \pm 0.04$ & $1.18 \pm 0.11$ & 4.11 \\
$28-33$ & $79.01 \pm 0.04$ & $14.21 \pm 0.38$ & $1.21 \pm 0.13$ & 4.34 \\
$34-39$ & $78.9 \pm 0.13$ & $14.89 \pm 0.16$ & $1.22 \pm 0.48$ & 5.09 \\
$40-45$ & $77.73 \pm 0.12$ & $14.99 \pm 0.45$ & $1.23 \pm 0.50$ & 5.44 \\
$46-51$ & $77.21 \pm 0.04$ & $15.09 \pm 0.28$ & $1.26 \pm 0.15$ & 5.56 \\
\hline
\end{tabular}

Table 3. Correlation between different nutrients and the prevalence and intensity of parasites in C. batrachus and C. gariepinus

\begin{tabular}{|c|c|c|}
\hline Correlation between & $\begin{array}{c}\text { In C. batrachus } \\
(\mathrm{r})\end{array}$ & $\begin{array}{c}\text { In C. gariepinus } \\
(\mathrm{r})\end{array}$ \\
\hline Moisture and protein & $0.562 ; \mathrm{p}>0.001$ & $0.615 ; \mathrm{p}>0.001$ \\
\hline Moisture and fat & $0.523 ; \mathrm{p}>0.001$ & $0.701 ; \mathrm{p}>0.001$ \\
\hline Moisture and carbohydrate & $0.759 ; \mathrm{p}>0.001$ & $0.816 ; \mathrm{p}>0.001$ \\
\hline Moisture and prevalence of infestation & $-0.129 ; \mathrm{p}>0.01$ & $0.164 ; \mathrm{p}>0.01$ \\
\hline Moisture and intensity of parasites & $-0.168 ; \mathrm{p}>0.01$ & $-0.336 ; \mathrm{p}>0.01$ \\
\hline Protein and fat & $0.505 ; \mathrm{p}>0.001$ & $0.738 ; \mathrm{p}>0.001$ \\
\hline Protein and carbohydrate & $0.689 ; \mathrm{p}>0.001$ & $0.784 ; \mathrm{p}>0.001$ \\
\hline Protein and prevalence of infestation & $-0.106 ; p>0.01$ & $0.231 ; \mathrm{p}>0.01$ \\
\hline Protein and intensity of parasites & $0.203 ; \mathrm{p}>0.01$ & $-0.247 ; \mathrm{p}>0.01$ \\
\hline Fat and carbohydrate & $0.735 ; \mathrm{p}>0.001$ & $0.855 ; \mathrm{p}>0.001$ \\
\hline Fat and prevalence of infestation & $0.016 ; \mathrm{p}>0.01$ & $0.123 ; \mathrm{p}>0.01$ \\
\hline Fat and intensity of parasites & $0.327 ; \mathrm{p}>0.01$ & $0.017 ; \mathrm{p}>0.01$ \\
\hline Carbohydrate and prevalence of infestation & $-0.145 ; \mathrm{p}>0.01$ & $0.184 ; \mathrm{p}>0.01$ \\
\hline Carbohydrate and intensity of parasites & $-0.199 ; \mathrm{p}>0.01$ & $0.136 ; \mathrm{p}>0.01$ \\
\hline
\end{tabular}

The percentage of protein content presented a direct correlation with the percentage of fat $(\mathrm{r}=0.505, \mathrm{p}>0.001)$ and carbohydrate $(\mathrm{r}=0.689, \mathrm{p}>0.001)$ in C. batrachus and similarly in C. gariepinus the protein contents with the fat ( $\mathrm{r}$ $=0.738, \mathrm{p}>0.001)$ and carbohydrate $(\mathrm{r}=0.784, \mathrm{p}>0.001)$ (Table 3). D. penetrans was the most dominant parasite in both $C$. batrachus and $C$. gariepinus to be infected stomach and anterior intestine. The pathological effects due to the $D$. penetrans infestation were much severe in $C$. batrachus than in $C$. gariepinus. In $C$. batrachus, the correlation of protein components with prevalence of $D$. penetrans was positive $(r=0.106, p>0.01)$. In C. gariepinus, the correlation of coefficient of percentage of protein content with prevalence of D. penetrans was $r=0.199, p>0.01$ and with intensity was $r=0.029, p>0.01$ (Table 4). 
Table 4. Correlation between different nutrients and the prevalence and intensity of $D$. penetr ans in C. batrachus and C. gariepinus

\begin{tabular}{lcc}
\hline Correlation between & $\begin{array}{c}\text { In C. Batrachus } \\
(\mathrm{r})\end{array}$ & $\begin{array}{c}\text { In C. gariepinus } \\
(\mathrm{r})\end{array}$ \\
\hline Protein and prevalence of infestation & $0.106 ; \mathrm{p}>0.01$ & $0.199 ; \mathrm{p}>0.01$ \\
Protein and intensity of parasites & $0.025 ; \mathrm{p}>0.01$ & $-0.343 ;>0.01$ \\
Moisture and prevalence of infestation & $-0.252 ; \mathrm{p}>0.01$ & $0.104 ; \mathrm{p}>0.01$ \\
Moisture and intensity of parasites & $0.221 ; \mathrm{p}>0.01$ & $-0.085 ;>0.01$ \\
Carbohydrate and prevalence of infestation & $-0.013 ; \mathrm{p}>0.01$ & $0.249 ; \mathrm{p}>0.01$ \\
Carbohydrate and intensity of parasites & $-0.100 ; \mathrm{p}>0.01$ & $0.029 ; \mathrm{p}>0.01$ \\
\hline
\end{tabular}

Moisture: The moisture contents were slightly higher in C. gariepinus (78.62 $\pm 0.42)$ than $C$. batrachus $(78.25 \pm 0.25)$. The percentage of moisture in infected C. batrachus $(77.07 \pm 0.16)$ was lower than non-infected $(78.25 \pm 0.25)$ and the moisture content was also lower in infected C. gariepinus $(77.53 \pm 0.09)$ than non-infected $(78.62 \pm 0.42)$. In $C$. batrachus, the percentage of moisture was higher in rainy season (September, 2014, $79.18 \pm 0.06 \mathrm{~g} / 100 \mathrm{~g}$ and September, $2015,79.19 \pm 0.14 \mathrm{~g} / 100 \mathrm{~g})$. While, the lower moisture content was recorded in winter (January, 2015, $76.75 \pm 0.02 \mathrm{~g} / 100 \mathrm{~g}$ and January, 2016, $76.72 \pm 0.02$ $\mathrm{g} / 100 \mathrm{~g})$. The pattern of seasonal variation of percentage of protein in $C$. gariepinus was recorded maximum in rainy season (July 2014, $79.36 \pm 0.06$ $\mathrm{g} / 100 \mathrm{~g}$ and July $2015,79.4 \pm 0.02 \mathrm{~g} / 100 \mathrm{~g}$ ) and the value was lowest during winter (November 2014, 77.01 $\pm 0.01 \mathrm{~g} / 100 \mathrm{~g}$ and November 2015, $77.06 \pm 0.11$ g/100 g). In both C. batrachus and C. gariepinus, the prevalence and intensity of infestation showed a peak during winter and summer (Figs 5 and 6).

In $C$. batrachus and C. gariepinus the average value of moisture contents was higher in smaller length groups of fishes than the larger groups. The difference of percentage of moisture in largest length group $(37-41 \mathrm{~cm})$ of $C$. batrachus was markedly low $(76.75 \pm 0.09 \mathrm{~g} / 100 \mathrm{~g})$ while, highest percentage of moisture contents was $(79.19 \pm 0.14 \mathrm{~g} / 100 \mathrm{~g})$ recorded in smallest length group $(12-16 \mathrm{~cm})$. The variation of percentage of moisture contents in different length

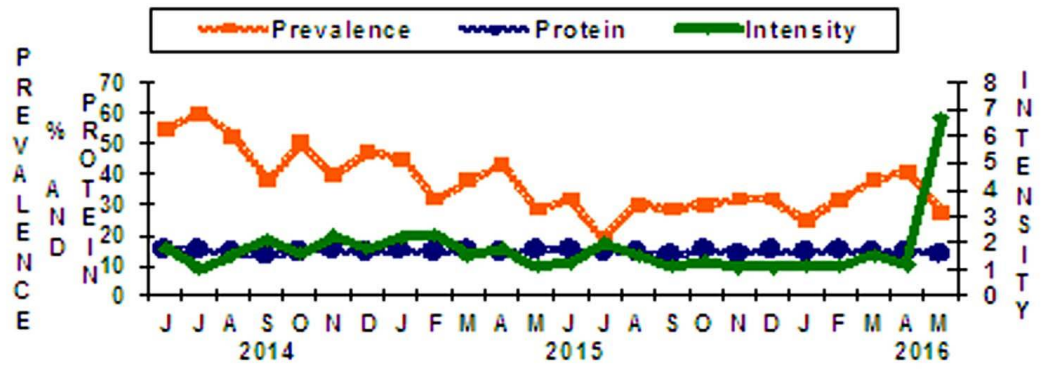

Fig. 4. Correlation of protein content with intensity and infestation of total parasites in C. gariepinus. 


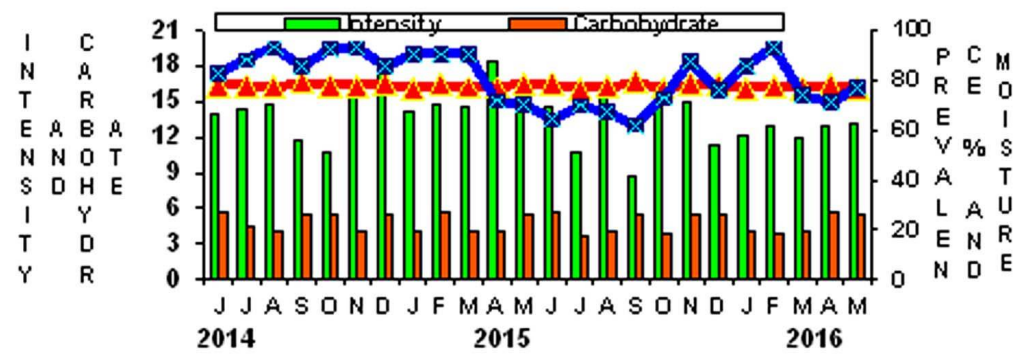

Fig. 5. Correlation of moisture and carbohydrate content with intensity and infestation of total parasites in C.batrachus.

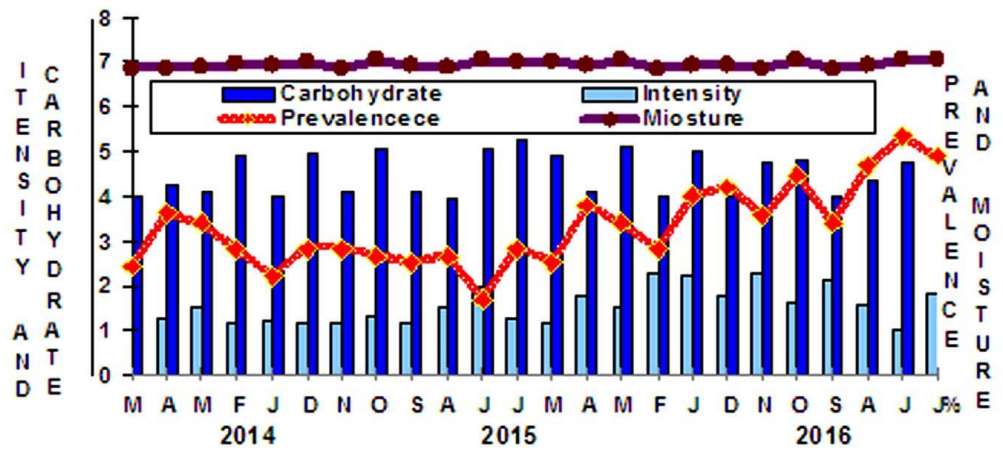

Fig. 6. Correlation of moisture and carbohydrate content with intensity and infestation of total parasites in C. gariepinus.

groups of C. gariepinus found quite higher $(79.4 \pm 0.06 \mathrm{~g} / 100 \mathrm{~g})$ in smaller fishes $(16-21 \mathrm{~cm})$ than the larger fishes (Tables 1 and 2). From Table 3, it also appeared that the percentage of moisture maintained a direct correlation with percentage of protein $(\mathrm{r}=0.562, \mathrm{p}>0.001)$, fat $(\mathrm{r}=0.523, \mathrm{p}>0.001)$ and carbohydrate $(\mathrm{r}=0.759, \mathrm{p}>0.001)$ in $C$. batrachus and similarly in $C$. gariepinus in case of protein $(\mathrm{r}=0.615, \mathrm{p}>0.001)$, fat $(\mathrm{r}=0.701, \mathrm{p}>0.001)$ and carbohydrate $(r=0.816, p>0.001)$, respectively. The variation of moisture content was directly and inversely correlated with prevalence $(\mathrm{r}=-0.252 ; \mathrm{p}>$ $0.01)$ and intensity of $(\mathrm{r}=0.221, \mathrm{p}>0.01)$ of $D$. penetrans in $C$. batrachus and C. gariepinus $(\mathrm{r}=0.104, \mathrm{p}>0.01$ and $\mathrm{r}=-0.085, \mathrm{p}>0.001$, respectively) (Table 4).

Carbohydrate: The variation in the percentage of carbohydrates in $C$. batrachus and C. gariepinus was less pronounced than those of protein and moisture. There was little difference between average total carbohydrate values of two Clarias spp. High percentage (5.53) was observed in C. batrachus than $C$. gariepinus (4.95) (Figs 1 and 2). From Table 3, it revealed that the percentage of carbohydrate showed a strong correlation with percentage of fat $(\mathrm{r}=0.735, \mathrm{p}>$ $0.001)$ in C. batrachus and in C. gariepinus $(\mathrm{r}=0.855, \mathrm{p}>0.001)$. There was 
inverse correlation between the percentage of carbohydrate with prevalence of parasites in C. batrachus $(\mathrm{r}=-0.145, \mathrm{p}>0.01)$ and in C. gariepinus $(\mathrm{r} 0.199, \mathrm{p}>$ 0.01 ). The carbohydrate values were higher during summer (May, 2015, 5.6\% and May, 2016, 5.6\%) in C. batrachus and were lower during rainy season (August, 2014, 4.04\% and July, 2015, 3.8\%). The highest values of carbohydrate in C. gariepinus was in summer (June 2014, 5.56\% and June, 2015, 5.25\%) while, the lowest values was in rainy season (September, 2014, $4 \%$ and August, 2015, 3.94\%) (Figs 5 and 6).

The difference of carbohydrate content from small to large C. batrachus was higher (5.58\%) in largest length group $(37-41 \mathrm{~cm})$, while smallest length group $(12-16 \mathrm{~cm})$ showed lower value of carbohydrates $(3.9 \%)$. The lowest value of carbohydrate content (3.95\%) was observed in 16-21 cm length group of $C$. gariepinus and with gradual increase in successive length group, reached highest (5.56\%) in 45-51 cm length group (Tables 1 and 2).

Fat: Comparison of the average fat content of C. gariepinus contained higher $(1.19 \pm 0.09)$ fat value than those of $C$. batrachus $(1.2 \pm 0.3)$. The correlation of fat contents with moisture, protein and carbohydrate was direct and significant in both the Clarias spp. (Table 3). The infestation ( $\mathrm{r}=-0.016 ; \mathrm{p}>0.01)$ and intensity of parasite $(\mathrm{r}=0.327, \mathrm{p}>0.01)$ in C. batrachus and C. gariepinus $(\mathrm{r}=$ $0.123, \mathrm{p}>0.01$ and $\mathrm{r}=0.017, \mathrm{p}>0.01$ ) maintained a weak correlation with fat content. The infestation and intensity of $D$. penetrans affected a little to reducing the fat content level in infected fishes. In present study, in $C$. batrachus, the percentages of fat were higher during winter $(1.390 . \pm 04 \mathrm{~g} / 100$ g, in February, 2015 and $1.32 \pm 0.02$, in December, 2015) and were lower in rainy season ( $1.00 \pm 0.12 \mathrm{~g} / 100 \mathrm{~g}$ in April, 2015 and $0.9 \pm 0.01 \mathrm{~g} / 100 \mathrm{~g}$ in April, 2016). Similarly, in C. gariepinus, the peaks being evident during winter (1.28 $\pm 0.13 \mathrm{~g} / 100 \mathrm{~g}$ in January, 2015 and $1.22 \pm 0.48$, in December, 2016) and the fat contents presents as lowest in summer (1.04 \pm 0.50, in April 2015 and 1.00 $\pm 0.02 \mathrm{~g} / 100 \mathrm{~g}$, in March, 2016) (Figs 7 and 8).

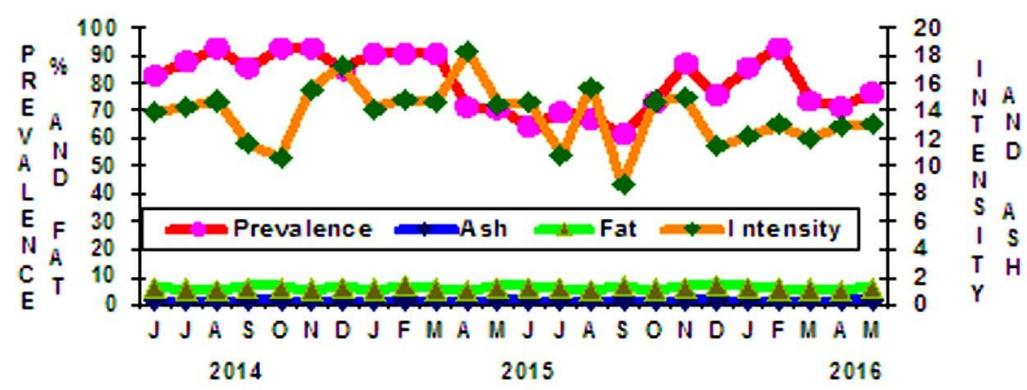

Fig. 7. Correlation of ash and fat content with intensity and infestation of total parasites in C. batrachus. 


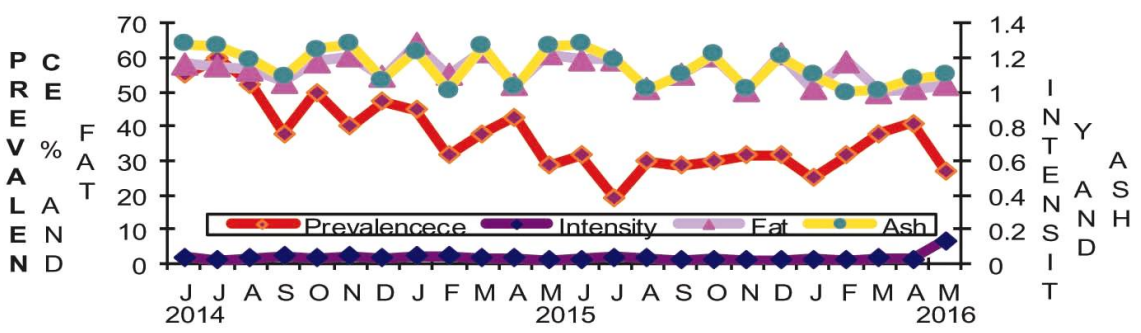

Fig. 8. Correlation of ash and fat content with intensity and infestation of total parasites in C. gariepinus.

The variation of percentage of fat contents in different length groups of $C$. batrachus was not so remarkable $(41 \mathrm{~cm})$ than the smaller length group (12 - 16 $\mathrm{cm}$ ) (Table 1). The variation of percentage of fat in the smallest length group (16 - $21 \mathrm{~cm})$ in C. gariepinus was low $(1.01 \pm 0.02 \mathrm{~g} / 100 \mathrm{~g})$ while, highest fat content (1.26 $\pm 0.15 \mathrm{~g} / 100 \mathrm{~g})$ was observed the largest length group $(46-51 \mathrm{~cm})$ (Table 2).

Ash: Low ash percentage was recorded in C. batrachus in rainy season (1.01 \pm 0.02 g/100 g, in August, 2014 and $1.0 \pm 0.03$ g/100 g, in August, 2015) and the highest percentage of ash was observed in winter $(1.45 \pm 0.32 \mathrm{~g} / 100 \mathrm{~g}$, in December, 2014 and $1.45 \pm 0.09 \mathrm{~g} / 100 \mathrm{~g}$, in December, 2015) (Fig. 7). In C. gariepinus, comparatively higher percentages of ash contents were recorded in summer $(1.28 \pm 0.50 \mathrm{~g} / 100 \mathrm{~g}$, in June 2014 and $1.28 \pm 0.14 \mathrm{~g} / 100 \mathrm{~g}$, in June, 2015). The lower percentage was noticed in winter $(1.01 \pm 0.10 \mathrm{~g} / 100 \mathrm{~g}$, in February, 2015) and summer (1.00 $\pm 0.07 \mathrm{~g} / 100 \mathrm{~g}$, in March, 2016) (Fig. 8). It appeared that the average ash content was slightly higher in C. batrachus $(1.42$ $\pm 0.12 \mathrm{~g} / 100 \mathrm{~g}$ ) than in C. gariepinus (1.22 $\pm 0.23 \mathrm{~g} / 100 \mathrm{~g})$ (Figs 1 and 2).

The difference of nutritional components between infected and non-infected fish species indicates that the heavy infestation of parasites may decrease the nutritional values such as moisture, ash, fat, protein, and carbohydrate and energy production level. Many studies have been carried out over the past decades on the nutritional components of freshwater and marine fishes of Bangladesh. The several contents of nutrition level were higher in non-infected C. batrachus than non-infected C. gariepinus except moisture. Banu et al. 1991 worked on mineral contents of some freshwater fishes including C. batrachus. Seasonal effects due to breeding and spawning on the biochemical composition of the fishes have been reported by Jacqut and Creach (1961) and Jafri (1969). Sultana (1989) indicated that moisture content in C. batrachus was higher in summer and rainy seasons than in autumn and winter. The nutrient content level was higher in infected C. gariepinus than the infected C. batrachus except in protein. She related the variation in proximate composition with the seasonal 
fluctuation of parasite infection, and in summer and rainy seasons the parasite infestation in C. batrachus was maximum. In the winter, the fish's lipid profile values reach higher, the fish's nutritive quality grows rich, so the parasites get more food support.

Fish constitute an important source of essential macro- and micro-nutrients in which Bangladeshi have been shown to be chronically deficient (Ahmed et al.1982). The moisture performs a vital role as a solvent, mineral nutrients and other food stuff being transmitted in solution throughout the animal body and also essential for most of the physiological reactions in animal tissue.

Sultana et al. (1992) studied the seasonal variation effect of helminth infestation on protein and fat contents of Clarias batrachus. They reported that the values of protein and fat content in the infected fishes were consistently lower than those for the healthy ones among the cases examined, which support the present findings of fat and protein contents in infected and non-infected $C$. batrachus and C. gariepinus. Latifa et al. (1985) reported higher moisture and protein contents in the juvenile of Tilapia nilotica than the adults, while fat value was higher in the adults. Both $C$. batrachus and C. gariepinus showed the highest protein and moisture contents in winter and rainy seasons. Jafri and Khawaja (1969) noted lowest percentage of fat content in Wallago attu during March and April, and highest during June to July. Sreenivasan and Natarajan (1961) reported insignificant seasonal variations of fat in the muscle of $W$. attu. Adhikari and Noor (1967) reported that, during November to January, the body protein content remains maximum and oil increased approximately by sevenfolds in the body of Barbus puntius. They mentioned a reverse relationship between fat and protein. Dietary fat components were highest in the body of $C$. batrachus and C. gariepinus was during winter. The present observations agree with the maximum protein and fat contents during winter months but differed regarding the direct relationship between protein and moisture, and in the reverse relationship between fat and protein. Parasite can cause an effect on reduction of carbohydrate level due to infestation. C. batrachus can ensure the higher energy level than C. gariepinus for the patients who were advised to take fishes suffering from sickness to gain rapid energy level. The highest intensity of parasite was observed in summer and the highest lipid profile was found in summer, but the highest prevalence of infestation was found during winter in $C$. batrachus and in rainy season in C. gariepinus. It reveals that the population of parasite burden and infestation rate combined reduce the lipid profile level and showed the difference in infected and non-infected fishes. It is evident that the prevalence and intensity of infestation and nutritional components have also been analyzed. The helminth infestation can affect the nutritional quality of 
fish. Parasites number and prevalence rate can decrease the food value of fish but not the prime cause.

\section{LITERTURE CITED}

ADHIKARI, S. and NOOR, A. 1967. Seasonal variation in oil, water contents and solid matters in different organs of punti fish (Barbus putius). J. Sci. Res. 4: 53-63.

AHMED, K., MALEK, M. A., SALAMATULLAH, ADEB, K., BADRUN and N. BEGUM, M.1977. Nutritive values of Bangladesh food staffs. Records of the Institute of Nutrition and Food Science, University of Dhaka.

AHMED, A.T.A., MUSTAFA, G. and AHMED, M.N. 1982. The proximate composition of flesh and food of Telapia nilotica (L.) and T. mossambica (Peters). Dhaka Univ. Stud. Part B. 29 (2): 33-39.

AHMED, K. and HASSAN, N. 1981-1982. Nutrition survey of Rural Bangladesh, Institute of Nutrition and Food Science, University of Dhaka. pp 32-37.

ALI, S. M. 1990. Studies on the nematode parasites of fishes and birds found in Hydrabad State. Ind. J. Helminth. 8: 1-83.

BANU, C.P., SULTANA, S. and SALAMATULlAH, Q. 1991. Studies on the mineral contents of freshwater fish and meat. Bangladesh J. Zool. 19(1): 59-63.

CHANDRA, K.J. 2004. Fish Parasitology. Lima Printing Press. Chotta Bazar, Mymensingh. 179 pp.

CUI, Y. and WOOTTON, R.J. 2011. Effects of relation, temperature and body size on the body composition, energy contents and condition of the minnow, Phoxinus phxonius (L.) Journal of Fish Biology, 32:749-764.

GOPALAN, C., SASTRI, RBV and BALASUBRAMANIAN, S.C. 1971. Nutritive value of Indian foods. Hydrabad, India. Journal of Nutrition Education. 2(3): pp 115.

HAQUE, A. 1975. Chemical constituent and preservation of fish. J. BCSIR (Dac.). 10: 69-75.

JACQUOT, R. and CREACH, P.V. 1961. Less protides dupoisson et. Leur valeur alimentaire, congr. Intern d' etude sur be role due possiion dans 1, alimantaion, Inst. Oceanogr., Paris.11-58.

JAFRI, A.K. and KHAWAJA, D.K.. 1968. Seasonal changes in the biochemical composition of the freshwater murrel, Ophicephalus punctatus Bloch. Hydrobiologia. 32:1-2, 206-218.

JAFRI, A.K. 1969. Seasonal changes in the biochemical composition of the catfish Wallagonia attu (Bloch). Hydrobiologia. 33: 497-506.

KHUDA, Q.M., De, H.N. and KHAN, N.M. 1962. Biochemical and nutritional studies on East Pakistan fish. Pakistan J. Sci. Ind. Res. 3: 20-23.

LATIFA, G.A., LUTFUN, N., AZAD, C. and KHAN, M.R. 1982. Fat, Protein, Vitamin A, iron, calcium and magnecium contents of adult and juvenile Barbus stigma. Journal of Bangladesh Academy of Sciences. 6 (1 \& 2): 199-203.

LATIFA, G. L., MAHFUZA, Q.C., SUCHANA, K.C. and AZAD, C. 1985. Fat, protein, vitamin A, iron calcium and magnesium contents of adult and juvenile T. nilotica. Jour. Physiol. Phar. 1(1 ): 1719.

LATIFA, G.A.1990. Effect of age, season and parasitic infestation on the micro and macro nutrient contents of Anabas testudineus (Bloch). Proc. Seminer on Res. Findings in some Biotech. Aspects, 1990. 65-73.

RUBBI, S.F., MUJIBAR, M., KHAN, A.R., JAHAN, S.S. and MAJEDA, B. 1985. Proximate composition and quality of some commercial species of freshwater fishes. Bangladesh J. Sci. Res. 5(1): 1-20.

SREENIVASAN, A. and NATARAJAN, M.V. 1961. Variation in the chemical composition of three freshwater fishes of Bhavanisagar Reservoir. Indian J. Fish. 8: 436-439. 
SULTANA, K. 1989. Investigation on some guts helminthes of Clarias batrachus (L) and the changes of the nutritional status due to parasitic infection. M. Sc. thesis. Department of Zoology. University of Dhaka. pp 110.

SULTANA, Q., RHAHIM, K.A., AHMED, A.T.A. and RAHMAN, M. 1992. Effect of helminth infestation and seasonal variation on the nutritional quality of Clarias batrachus. (L.). Dhaka Univ. Stud. Part E. 7(1): 1-6.

(Manuscript received on 18 March 2019; revised on 24 April, 2019) 